\title{
9
}

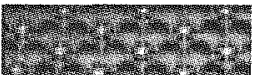

\section{The impact of WTO accession on FDI}

Chen Chunlai

FDI in China has been one of the most significant features of China's economic reform and opening up to the outside world. The gradual liberalisation of restrictions on FDI since 1979, and the government's commitment to further opening, have greatly improved the investment environment. Foreign firms have been attracted by the huge domestic market and pool of relatively well-educated, lowcost labour, making China one of the most attractive destinations for FDI in the world. By the end of 2001, China had attracted a total of over US $\$ 390$ billion in FDI inflows, making it the largest FDI recipient among developing economies and the second largest FDI recipient in the world.

In the WTO negotiation agreements, China agreed to reduce tariff and non-tariff barriers to trade in agriculture, manufactured goods, and services, remove a number of restrictions on FDI particularly in services, and improve protection of intellectual property rights.

Very few studies have incorporated investment or financial liberalisation in their estimation of FDI inflows after China's WTO accession. The most common results of these studies are that China's WTO accession would have a positive impact on its GDP growth, mainly through efficiency gains resulting from trade and investment liberalisation, and China's WTO accession would accelerate FDI inflows into China and increase the foreign ownership share in China's assets. 


\section{WTO AGREEMENTS RELATING TO FDI AND CHINA'S FDI POLICY}

The Agreement on Trade-Related Investment Measures (TRIMs) was achieved in the Uruguay Round multilateral negotiations of GATT. The overriding objective of the TRIMs Agreement is to promote the expansion and progressive liberalisation of world trade and to facilitate investment across international frontiers so as to increase the economic growth of all trading partners, particularly developing economy members, while ensuring free competition.

Because of the difficulties associated with bringing discipline to investment into the international trading framework, the TRIMs agreement has emerged as the shortest and most limited of the WTO agreements, with only nine Articles plus an Illustrative List. The TRIMs agreement applies to investment measures related to trade in goods only. TRIMs themselves are not defined. Instead, the Illustrative List of measures which are deemed to be WTO-inconsistent refers to measures which are mandatory or enforceable under domestic law or administrative ruling, or compliance. A TRIM may fall into at least one of the following five categories

- a firm is required to source a specified minimum proportion of its purchases from local sources (local content requirement

- a firm is required to achieve a specified import-export ratio in relation to local product embedded in the exports (trade balancing requirement)

- a firm's level of imports in relation to its export or local production (trade balancing restriction)

- a firm's access to foreign exchange is restricted (foreign exchange balancing restrictions)

- a firm's level of exports is restricted (export restrictions).

The most significant provisions of the TRIMs agreement relate to national treatment, elimination of quantitative restrictions, notification and transparency, and transitional arrangements. The TRIMs agreement has a number of positive elements. First, the adoption of specific investment-related disciplines should help to bring a greater degree of predictability into international investment flows. Second, it will improve the level of certainty for investors abroad by limiting the scope for governments to attach onerous conditions to investment approvals or to link them to the receipt of other advantages. Investors will also have the certainty that the notified TRIMs will be eliminated within a specified time period. Third, the agreement provides a greater level of transparency in investment rules through notification of 
WTO-inconsistent rules and through advice of publications in which information on TRIMs at both the national and sub-national level may be found. Fourth, the agreement reinforces the interrelationship between trade and investment, by noting the possible need for more work in the future in investment and competition policy, thereby emphasising the interconnected nature of government policy, and enhancing consistency between policies. Finally, the TRIMs Agreement provides that the principles of national treatment and most-favoured nation (MFN) apply to the use of trade-related investment measures.

However, there are also limitations to the TRIMs agreement. The main limitation is that it does not provide a comprehensive list of WTO-inconsistent TRIMs but is instead limited to a subset of what are generally referred to as performance requirements. It is unclear just how complete the Illustrative List is, and whether other measures not on the list could be held to be inconsistent within TRIMs obligations. In addition, the agreement is limited to goods and so does not include services.

Although the TRIMs agreement is the most relevant part of WTO agreements for FDI, it is not the only WTO instrument which has a bearing on investment measures. Other relevant WTO agreements include the General Agreement on Trade in Services (GATS) and the Agreement on Trade-Related Aspects of Intellectual Property Rights (TRIPS).

The GATS sets out the rights and obligations for non-discriminatory services trade. While it does not explicitly refer to investment measures, it does implicitly include provisions on investment through references to commercial presence. Commercial presence is one of the four modes of supply identified in GATS (the other three are cross-border trade, movement of suppliers, and movement of natural persons). Commercial presence is defined as any type of business or professional establishment, including through the constitution, acquisition or maintenance of a juridical person or the creation or maintenance of a branch or a representative office, within the territory of a member for the purpose of supplying a service. Member countries are required to schedule their commitments to liberalisation in particular sectors (that is, to provide market access and national treatment) in terms of the four modes of supply. In addition, countries are required to apply the principle of MFN in all sectors. This means that even where countries do not specify greater liberalisation in particular sectors, the MFN obligation will still apply. Given the direct link between investment and establishing commercial presence, it is clear that further liberalisation will directly influence investment flows. 
The agreement on TRIPs does not refer directly or even indirectly to investment. However, to the extent that foreign investment is related either to investment in products or process with an intellectual property content (that is, the value of the product is in part determined by the legal protection accorded to the intellectual property) or to licensing arrangements for technology transfer, decisions to invest may be affected by the level of intellectual property protection offered by the host government. The TRIPs agreement, which provides for minimum standards of protection and enforcement of intellectual property, may have some influence on the direction of investment flows.

FDI in China was prohibited prior to 1978. In order to achieve new objectives of economic growth and development, however, China began to relax restrictions on FDI into its domestic economy in 1979. Since then, the FDI regime has been liberalised gradually, especially since the early 1990s. Admittedly, China has achieved substantial progress in its FDI policy reform within a relatively short period. However, China's FDI policy regime still needs further liberalisation. On the one hand, China's current FDI policy is still relatively restricted in terms of FDI entry forms, foreign ownership shares, industry restrictions and performance requirements. On the other hand, China still extensively uses fiscal and other incentive policies to encourage some specific types of FDI; for example, export-oriented and technologically advanced FDI, and to induce FDl flows into some targeted regions and industries.

Table 9.1 presents an indicative list of China's current FDI policy relating to the key provisions of the TRIMs agreement. China's current FDI policy needs to be further improved in all aspects.

China has made substantial commitments in trade and investment liberalisation, especially in the automobile industry and services sector, and has agreed to comprehensively implement the TRIMs agreement after entering the WTO. Undoubtedly, the reduction in foreign investment barriers and liberalisation of the FDI regime will provide great opportunities for foreign investors to invest and operate business in China. Therefore, China's accession to the WTO will have a positive impact on China's FDI policy regime, particularly in the aspects of national treatment and transparency. Meanwhile, it will also help China to improve its competition policies, industrial policies and intellectual property rights protection and enforcement.

\section{IMPACT ON FDI INFLOWS TO CHINA}

FDl inflows into China grew steadily during the 1980 s, but increased very rapidly in 


\section{KEY PROVISIONS OFTRIMS AGREEMENT AND CHINA'S CURRENT FDI POLICY}

Provisions of TRIMs agreement National treatment

MFN status

Performance requirement and restrictions

Transparency
China's current FDI policy

Extensive restrictions in various sectors, particularly in services. Moving toward national treatment for incentives, which still favour foreign investors. Gives no preferences relating to the establishment, expansion and creation of foreign investment.

Requires local content in some industries.

Requires technology transfer and a certain level of technology content in some technologically advanced industries. Requires research and development activities in some industries. Requires foreign exchange balancing for all foreigninvested firms. Requires export performance for export-oriented foreign invested firms. Prohibition from foreign investment in some industries. Restrictions on types of entry and ownership shares in various sectors. Business scope restrictions in most service sectors. Geographic restrictions in most service sectors.

Extensive laws, regulations and guidelines relating to FDI.

Requires significant documentation in the application process.

Source: Author's compilation.

the 1990 s (Table 9.2). From 1979 to 2001 , China attracted over US $\$ 390$ billion in FDI inflows, making it the largest FDI recipient among the developing economies and the second largest FDI recipient in the world. However, FDI inflows into China slowed after 1997 and actually declined in 1999 and 2000. There was a moderate recovery in 2001.

The slowdown of FDI inflows into China in recent years could be explained by several factors. First, it is likely that high FDI inflows into China during the early 1990s were exceptional and will fall back to a more sustainable level in the long run. Second, there has been a slowdown from the surge in transfers of labour-intensive activities from neighbouring Asian economies. In addition, the East Asian financial crisis substantially weakened capability for outward investment of the Northeast and Southeast Asian economies. As a result, FDI flows into China from the 


$\begin{array}{cccc}\text { Year } & \begin{array}{c}\text { FDI inflows } \\ \text { (US\$ billion) }\end{array} & \text { Year } & \begin{array}{c}\text { FDI inflows } \\ \text { (US \$ billion) }\end{array} \\ 1979 & 0.1 & 1991 & 4.4 \\ 1980 & 0.2 & 1992 & 11.0 \\ 1981 & 0.4 & 1993 & 27.5 \\ 1982 & 0.4 & 1994 & 33.8 \\ 1983 & 0.6 & 1995 & 37.5 \\ 1984 & 1.3 & 1996 & 41.7 \\ 1985 & 1.7 & 1997 & 45.3 \\ 1986 & 1.9 & 1998 & 45.5 \\ 1987 & 2.3 & 1999 & 40.3 \\ 1988 & 3.2 & 2000 & 40.7 \\ 1989 & 3.4 & 2001 & 46.9 \\ 1990 & 3.5 & \text { Total } & 393.4\end{array}$

Note: Data for 2001 are from the Ministry of Foreign Trade and Economic Cooperation (MOFTEC). Source: State Statistical Bureau, various years. Zhongguo Tongji Nianjian (China Statistical Yearbook), Zhongguo Tongji Chubanshe, Beijing.

Northeast and Southeast Asian economies have declined substantially since 1997. Third, market rates of return to investment in China have not been as high as foreign investors expected. In many cases foreign investors' high hopes for China's market have been slow to materialise. Informal relationships and corruption still hinder many business transactions by foreigners. In addition, inefficient SOEs still dominate many key sectors of the economy. Finally, there are still restrictions on FDI, such as on ownership shares, modes of FDI entry, and regional and sectoral restrictions.

Therefore, China's accession to the WTO comes at a very critical time when China is facing difficulties in sustaining a high level of FDI inilows. Could China's accession to the WTO revive the trend of a high level of FDI inflows and bring greater inflows?

McKibbin and Wilcoxen (1998) explored the impact of trade liberalisation and financial liberalisation on China's economy by using a dynamic intertemporal general equilibrium model (DIGEM). According to their study, under the trade liberalisation scenario, China's tariff cuts would improve economic efficiency and raise the overall return to capital, which would in turn increase foreign investment. Under the financial liberalisation scenario, financial flows into China would increase very quickly.

Walmsley and Hertel (2000) estimated the economic effects of China's WTO ac- 
cession by using a dynamic GTAP model, which incorporates international capital mobility and ownership data. In their simulation, China's accession raises the rate of return to capital, thereby increasing foreign investment and capital stock, particularly in the first rive years following accession. Overall foreign ownership of China's capital increases relative to the baseline as a result of accession.

The United Nations Conference on Trade and Development (UNCTAD 2000) estimated that in the short term, China's WTO accession would have only a small effect on FDI flows into China, as investors adopt a wait-and-see attitude while reforms are being implemented. However, in the medium term, UNCTAD predicts FDI flows into China could increase from current levels of about US\$40 billion to US $\$ 60$ billion and possibly US $\$ 100$ billion annually if cross-border mergers and acquisitions are allowed.

Goldman Sachs (1999) examined China's reported April 1999 offer to the United States and projected that China's WTO accession would significantly boost China's economic growth, foreign investment and trade. According to the study, trade liberalisation and greater openness would boost productivity, expanding GDP growth. China's total trade (exports plus imports) and FDI flows would nearly double by 2005.

How much FDI will flow into China after China's accession to the WTO? Obviously, no one knows the exact figure. However, a rough estimate would still be useful in a policy evaluation of the impact of WTO accession on FDI inflows into China. Chen Chunlai (2001), using an empirical model, ${ }^{1}$ estimated future FDI inflows into China. According to the estimation (Table 9.3), after China's accession to the WTO, FDI inflows into China would increase moderately in the first two years, with annual FDI inflows around US $\$ 45$ billion. Then inflows would increase rapidly and considerably. In the medium term (2005), annual FDI inflows into China would reach over US $\$ 60$ billion, and in the long term (2010) roughly US $\$ 100$ billion.

In summary, China's WTO accession would have a positive impact on FDI in China. It would accelerate FDI inflows into China and increase the foreign ownership share in China's assets. However, the answer to whether China will benefit from WTO entry and realise its potential in attracting FDI inflows after accession to the WTO, largely depends on how China implements the WTO agreements, fulfils its WTO commitments, further reduces and eliminates trade and investment barriers and opens up more domestic markets, manages internal economic reforms (particularly the reform of SOEs), and enforces the protection of intellectual property rights. 


$\begin{array}{cccc} & \begin{array}{c}\text { Baseline scenario } \\ \text { (US } \$ \text { billion) }\end{array} & \begin{array}{c}\text { WTO scenario } \\ \text { (US\$ billion) }\end{array} & \begin{array}{c}\text { WTO over baseline } \\ (\%)\end{array} \\ 2000 & 40.1 & 40.1 & - \\ 2001 & 42.1 & 43.9 & 4.2 \\ 2002 & 44.2 & 48.1 & 8.7 \\ 2003 & 46.5 & 52.7 & 13.4 \\ 2004 & 48.8 & 57.8 & 18.4 \\ 2005 & 51.2 & 63.3 & 23.8 \\ 2006 & 53.7 & 69.6 & 29.7 \\ 2007 & 56.3 & 76.6 & 35.9 \\ 2008 & 59.1 & 84.3 & 42.7 \\ 2009 & 62.0 & 93.0 & 50.1 \\ 2010 & 65.0 & 102.7 & 58.1\end{array}$

Source: Chen Chunlai, 2001. 'The implications of China's WTO accession for foreign direct investment in China', in The Implications of TIL for China's Domestic Economic Development and Policies, OECD, Paris.

\section{IMPACT ON THE COMPOSITION OF FDI SOURCES}

FDI in China comes from more than 100 economies across the world, but FDI into China has been overwhelmingly dominated by the developing economies, particularly the Asian newly industrialised economies (NIEs). In terms of individual investors, FDI in China has been dominated by four investors-Hong Kong, Taiwan, the United States and Japan.

As Table 9.4 shows, during the period 1983-2000, investment from developing economies dominated FDI in China, accounting for 74.2 per cent of the total accumulated FDI inflows. Among the developing source economies, as a group, the NIEs have been the largest investors, accounting for 64.7 per cent of the total. Within the NIEs, Hong Kong has held the dominant position, accounting for 49.6 per cent, followed by Taiwan (7.5 per cent). In contrast, in the same period, the accumulated FDI inflows from industrial source economies accounted for only 25.8 per cent of total FDI inflows into China. Among the industrial economies, the United States and Japan are the most important investors, each accounting for 8.6 per cent and 8.1 per cent respectively, while the combined share of the other industrial economies is 9.1 per cent. Apart from the United Kingdom, Germany and France, no other individual industrial economy has contributed more than 1 per cent of the total accumulated FDI inflows to China. 


\section{TABLE 9.4}

Source

NIEs

Hong Kong

Taiwan

Singapore

South Korea

ASEAN

Japan

United States

West Europe

UK

Germany

France

Other industrial economies

Other Asia

East Europe

Latin America

Africa

Others

Developing economies

Industrial economies

Total
ACCUMULATED FDI INFLOWS INTO CHINA BY SOURCE ECONOMIES

Total FDI inflows Share

1983-2000

(US\$billion)

222.3

170.3

25.6

16.3

10.0

1983-2000

(\%)

64.7

49.6

7.5

4.8

2.9

5.9

1.7

27.7

29.7

8.1

8.6

26.6

7.7

8.5

2.5

5.7

1.7

4.1

1.2

4.6

1.3

4.7

1.3

0.5

0.1

14.7

4.3

0.8

0.2

6.1

1.8

254.9

74.2

25.8

343.4

Note: Calculations are based on 1995 constant US dollar prices.

Sources: State Statistical Bureau, various years. Zhongguo Tongii Nianjian [China Statistical Yearbook], Zhongguo Tongji Chubanshe, Beijing.

Obviously the current composition of FDI sources in China needs to be diversified if China is to benefit more from FDI. The diversification of FDI sources is not only necessary for China to attract a greater quantity of FDI inflows, but is also important in order for China to attract high quality FDI inflows. China's accession to the WTO provides a great opportunity for China to improve and diversify its FDI sources and therefore will have a significant impact on the composition of FDI sources in China.

In general, with the implementation of trade and investment liberalisation after China's accession to the WTO, both developing and industrial economies would increase, their investments in China as a result of the improvement of the overall 
investment environment and the reduction of trade and investment barriers in China.

For developing economies (mainly the NIEs), because they have moderate technological and innovative capabilities and are at a middle stage of economic development, the ownership advantages possessed by their enterprises are more concentrated in the forms of labour-intensive production technology, standardised manufactured products and well-established export market networks. Obviously, China, being relatively abundant in labour resources and having a comparative advantage in labour-intensive activities, is a very attractive location for developing economy investors, particularly for export-oriented FDI. After China's accession to the WTO, on the one hand, China will reduce trade and investment barriers and improve the investment environment; on the other hand, China's export markets will also be greatly enlarged as the member economies-particularly the industrial economieswill open more domestic markets for China's exports. Therefore, there are great incentives for developing country investors to increase total FDI in China in general and to increase export-oriented FDI in China in particular. It is expected that China will remain an important host economy for investment from developing economies, particularly the NIEs, after China's accession to the WTO.

In general, enterprises from economies with high technological and innovative capabilities and high overall economic development, will possess more ownership advantages in the forms of high technology, product differentiation, managerial and entrepreneurial skills, and knowledge-based intangible assets. Because of these firms'specific ownership advantages, FDI from industrial economies is more market-oriented. The general implication is that host economies with larger market size, faster economic growth and a higher degree of economic development will attract more market-oriented FDI. China's huge domestic market, fast economic growth and increasing per capita income are very attractive for industrial economy investors, particularly for market-oriented FDI. Therefore, China's accession to the WTO will provide great opportunities for industrial economy investors to explore China's huge domestic markets. It is expected that with the implementation of WTO agreements and fulfilment of its commitments to the WTO in trade and investment liberalisation (particularly in the areas of strengthening intellectual property rights protection, opening more economic sectors, especially the services sector, to FDI, and allowing and encouraging cross-border mergers and acquisitions [M\&As]), China will become an increasingly important host economy for FDI from industrial economies. This will not only increase total FDI inflows from industrial economies, but will 


\section{FIGURE 9.1 REGIONAL DISTRIBUTION OFACCUMULATED FDI}

INFLOWS INTO CHINA, 1983-2000

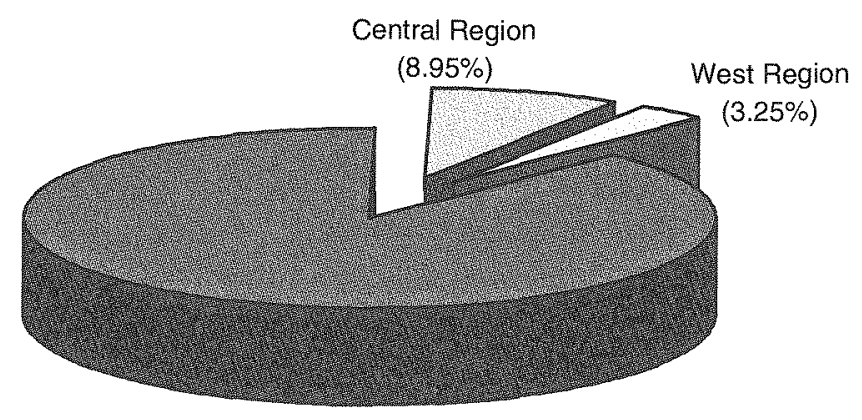

East Region

$(87.80 \%)$

Note: Calculations are based on 1995 constant US $\$$ prices.

Source: State Statistical Bureau, various years. Zhongguo Tongji Nianjian (China Statistical Yearbook), Zhongguo Tongii Chubanshe, Beijing.

also increase the quality of FDI inflows into China.

\section{IMPACT ON THE REGIONAL DISTRIBUTION OF FDI IN CHINA}

Since China began to attract FDI into its economy, the regional distribution of FDI within China has been very uneven. FDl inflows into China in the 1980 s were overwhelmingly concentrated in the four special economic zones and the two municipalities of Beijing and Shanghai. With the development of overall economic reform and the nationwide implementation of open policies for FDI in the 1990s, FDI in. flows into China gradually spread from the initial concentrated areas to other provinces. Increasingly the most important areas for hosting FDI are the Yangzi River Delta including Jiangsu, Shanghai and Zhejiang, and the Bohai Gulf including Shandong, Hebei, Tianjin and Liaoning. Several provinces, such as Jilin, Heilongjiang, Anhui, Jiangxi, Henan, Hubei and Hunan in the central region, and Sichuan and Shaanxi in the west region, also experienced relatively large increases in FDI inflows in the 1990s. 
Comparing the three province groups of the east, central and west regions, ${ }^{2}$ the east region provinces have overwhelmingly dominated the other two province groups in attracting FDI. For the period 1983-2000 the percentage shares in the national total of accumulated FDI inflows were 87.8 per cent for the eastern region provinces, 8.9 per cent for the central region provinces, and only 3.3 per cent for the western region provinces (Figure 9.1). This uneven regional distribution of FDI has to a certain extent helped to enlarge the gap in income levels between the east and the central and west regions.

With China's accession to the WTO, it is expected that trade and investment liberalisation will bring more benefits to the east region than to the rest of the country, especially than to the west region. As a result, after accession, economic growth in the east region will be higher and faster than in the west region. Consequently, it is expected that more FDI will flow into the east region.

The attractiveness of the east region for FDI is its relatively more liberalised and industrial economy, closer connections with the outside world, better infrastructure, a higher level of scientific research and technical innovation, and a higher quality labour force. Therefore, with further liberalisation in trade and investment after China's accession to the WTO, the east region will attract more FDI inflows. Labourintensive export-oriented FDI in the manufacturing sector is likely to maintain a positive and important role in export promotion, economic growth and employment creation. Market-oriented FDI is expected to continue to show an upward trend in the years following China's accession to the WTO, especially in the east region.

To boost economic growth and therefore reduce the gap of economic development between the east region and the central and west regions, the Chinese government launched the West Development Strategy in $1998 .{ }^{3}$ The Strategy emphasises infrastructure development, environmental protection, industrial structural readjustment, the development of sciences and education, and economic reform and openness. To realise these goals, four concrete measures are to be implemented. First, the central government will dramatically increase investment in the central and west regions, and increase transfer payments from the central government budget. Second, the central and west regions will increase the degree of openness and implement more open policies, in particular by opening more areas and sectors to FDI. Third, enterprises - especially foreign-invested enterprises (FIEs)-in the east region are encouraged to invest and to do business in the central and west regions. Fourth, the central and west regions will enhance the development of 
sciences and education in order to attract and improve human resources.

To improve the investment environment and accelerate economic growth in the west region, China will need to invest heavily in infrastructure development in the west region. According to the West Development Strategy, the major infrastructure projects include investing 120 billion yuan in highway and road construction from 2000-2020; investing 100 billion yuan in large and medium-size railway projects from 2000-2005; creating a hydro-electricity generation base in the west region and constructing a national electricity supply network in order to transport electricity from the west region to the east region from 2000-2015; investing 300 billion yuan in gas pipeline construction to transport natural gas from the west region to the east region from 2000-2007; and constructing more airports in the west region (Office of the Leading Group for West Development of the State Council 2000).

Undoubtedly, the West Development Strategy and the further opening of the central and west regions have provided great opportunities for foreign investors. The comparative advantages of the central and west regions are rich natural resources, low labour costs and growing markets. In addition, there are many SOEs in the central and west regions, with a huge amount of idle capital stock. Currently China is stipulating relevant laws and regulations on cross-border M\&As and foreign investors are encouraged to participate in SOE reform and transformation through M\&As. With the deepening of SOE reform and the participation of foreign investment through M\&As, it is expected that in the medium and long run more foreign capital will flow into the central and west regions.

It is most likely that in the short run following China's accession to the WTO, regional economic development will be uneven, and as a result, the uneven regional distribution of FDI between the east region and the central and west regions will be reinforced. However, in the medium and long run, with the implementation of the West Development Strategy, and economic development in the central and west regions, it is reasonable to expect a greater flow of FDI to the central and west regions.

\section{IMPACT ON THE SECTORAL DISTRIBUTION OF FDI IN CHINA}

The sectoral distribution of FDI in China is characterised by the concentration of FDI in the manufacturing sector. At the end of 2000, the primary sector attracted 2.2 per cent, the manufacturing sector 61.0 per cent, and the services sector 36.8 per cent, of total contracted FDI inflows into China (Figure 9.2). However, in the services sector most FDI was in the real estate industry, which accounted for 24.0 


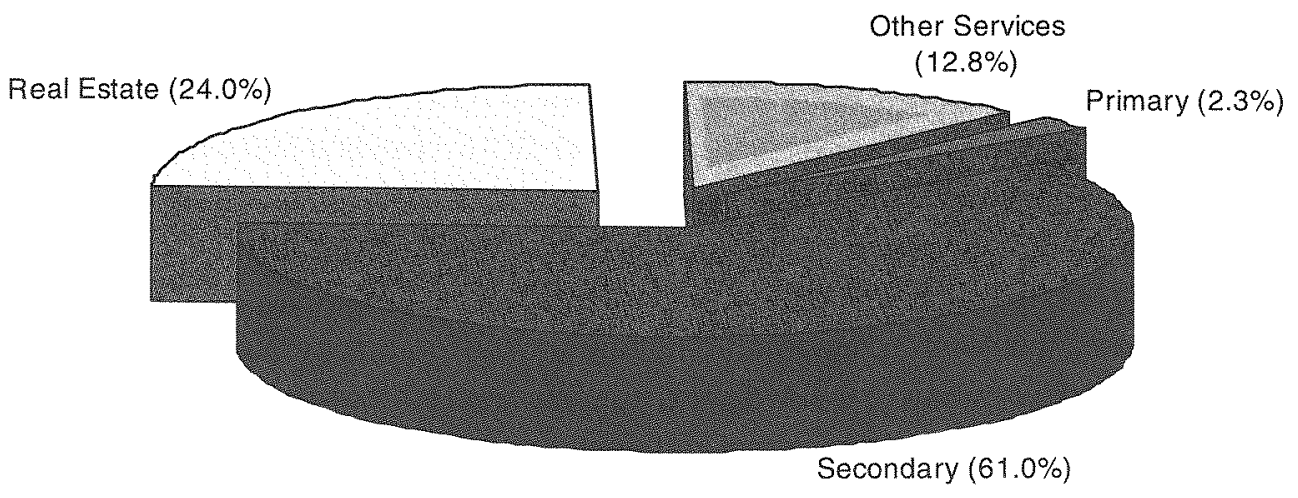

Note: Calculations are based on the contracted value of FDI.

Source: State Statistical Bureau, various years. Zhongguo Duiwai Jingji Tongji Nianjian [China Foreign Economic Statistical Yearbook] and Zhongguo Tongji Nianjian [China Statistical Yearbook], Zhongguo Tongji Chubanshe, Beijing.

per cent of total FDI inflows to China. As a result, the other services industries attracted only 12.8 per cent of total FDI inflows.

The current sectoral distribution of FDl in China is biased towards the manufacturing sector. Although FDI inflows into the primary and services sectors have been increasing since the mid 1990s, the volume of FDI inflows into these sectors is still low when compared to FDl inflows to the manufacturing sector.

Following China's accession to the WTO, the sectoral distribution of FDI inflows will experience some changes. The general trend will be for the proportion of FDI in the manufacturing sector to decline, while the proportion of FDI in the services sector-particularly in finance, insurance, commerce, telecommunications and auxiliary services-will increase. However, changes to the sectoral distribution of FDI will primarily depend on the successful implementation of China's WTO commitments and the degree of market opening to foreign investors. 


\section{Primary sector}

Of all the sectors of the Chinese economy, the primary sector has received the smallest amount of FDI. By the end of 2000, FDI in China's primary sector was around US $\$ 7.9$ billion, of which US $\$ 4.7$ billion was in agriculture and US $\$ 3.2$ billion was in ocean oil and natural gas exploration, mining and other primary industries. It should be noted that most foreign investments in ocean oil and natural gas exploration are recorded as other foreign investments which are not included in China's FDI statistics.

Agriculture was one of the earliest sectors to open up to FDI. However, the success of agriculture in attracting FDI has not been impressive when viewed in the context of the large volume of FDI inflows over the last two decades. There are many reasons for the poor performance of agriculture in attracting FDI, but there are two that are probably most important. First, China's agricultural land tenure system, and hence, the traditional small-scale family-based agricultural production method has greatly limited the inflows of agricultural FDI and large-scale production and advanced technology. Second, government controls over production, pricing, purchase, storage, transportation, domestic sales, and international exports of grains and other major agricultural products have been a significant disincentive for foreigers to invest in China's agricultural sector. Therefore, China will not attract large FDI inflows into its agricultural sector without fundamentally changing its land tenure system and dramatically reforming and liberalising its grain and major agricultural products marketing system. China's accession to the WTO provides a good opportunity for China to reform and restructure its agricultural sector in a new environment of international competition.

In general, China has no comparative advantage in land-intensive grain production. However, with its abundant and cheap labour resources, China has a comparative advantage in labour-intensive horticultural and animal husbandry production. After accession to the WTO and the restructuring of China's agricultural production structure, China will have the potential to expand its production and exports of horticultural products and animal products. Therefore, the horticultural and animal husbandry industries have great potential to attract FDI inflows after China's accession.

However, China's potential to expand exports of horticultural products and animal products is limited by deficiencies in its technologies, capital and marketing networks. Therefore, there is also a great opportunity for foreign investors to invest in areas such as horticultural products and animal products quality upgrading, 
processing, fresh preservation, packaging, storing and transportation. In addition, with the development of the animal husbandry industry, the feed processing industry is also a very attractive sector for FDI.

The oil and natural gas exploration, and mining industries will have great potential to attract foreign investment if China removes the restrictions on foreign ownership shares, types of investment and operation scopes on FDI in these industries. It is expected that after China's accession to the WTO, the oil and natural gas exploration and mining industries will attract more FDI inflows as China gradually reduces and eventually eliminates the restrictions on FDI in these industries. In addition, China's west region is well-endowed with natural resources, particularly oil, natural gas and mines. With the implementation of the West Development Strategy and the improvement of the overall investment environment, particularly in infrastructure and open policies in the west region, it is expected that the west region will attract more FDI inflows into its resource-based primary industries.

\section{Manufacturing sector}

The manufacturing sector is the largest FDI recipient sector in China. By the end of 2000 , the manufacturing sector had attracted US $\$ 210.9$ billion in FDI, accounting for over 60 per cent of total FDI inflows to China. In terms of the industrial distribution of FDI in the manufacturing sector, 40.7 per cent of total manufacturing FDI went to labour-intensive industries, while capital-intensive industries and technology-intensive industries accounted for 24.4 per cent and 34.7 per cent, respectively (Figure 9.3).

Studies of the impact of China's accession to the WTO predict that after accession, labour-intensive manufacturing industries-especially textiles and clothing industries-will grow rapidly, led by a large expansion of China's exports. This expansion will follow from industrial economies' reduction of import tariffs and elimination of quotas on imports of China's labour-intensive manufactured goods. However, to realise this potential, China needs to introduce foreign capital, technology and advanced equipment to help upgrade its relatively backward labour-intensive industries, in order to compete in global markets. Therefore, there are great opportunities for foreign investors to invest in China's labour-intensive and export-oriented manufacturing industries. It is expected that with trade and investment liberalisation after accession to the WTO, China will attract more FDI inflows into its labour-intensive and export-oriented industries. While the southeast coastal region will still be the 


\section{FIGURE $9.3 \quad$ COMPOSITION OF FIES BY INDUSTRY GROUPS OF FACTORINTENSITY (END 2000)}

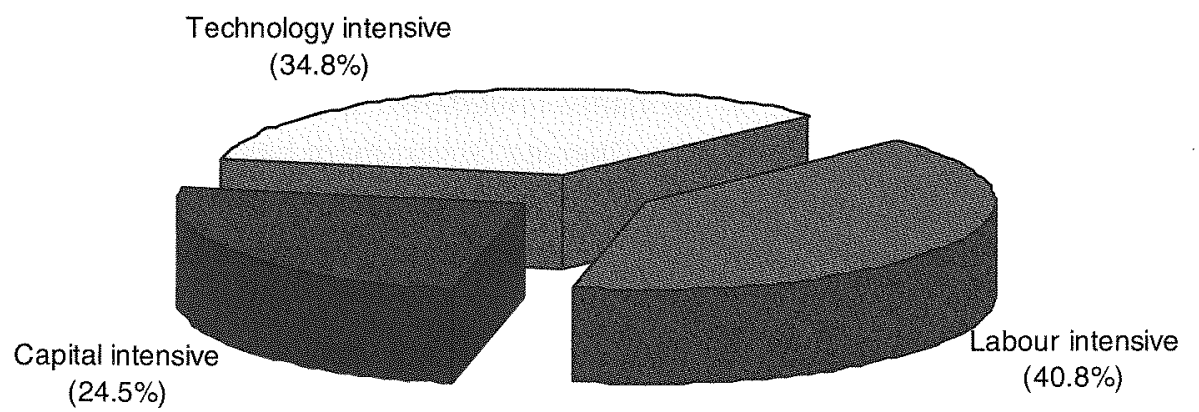

Note: Calculations are based on the total assets of FIEs at the end of 2000.

Source: State Statistical Bureau, 2001. Zhongguo Tongji Nianjian 2001 (China Statistical Yearbook 2001), Zhongguo Tongji Chubanshe, Beijing.

main receipt of labour-intensive and export-oriented FDI, following the implementation of the West Development Strategy and the improvement of the investment environment, especially the breakdown of regulatory barriers and reduction of tranport and transaction cost to internal trade, the central and west regions will become increasingly attractive to foreign investors. Thus, more labour-intensive FDI is expected to flow into the central and west regions in the medium and long run, causing a gradual shift of labour-intensive FDI from the southeast coastal region to the central and west regions as these regions' comparative advantages change in the process of economic development.

Generally speaking, China's capital-intensive and technology-intensive manufacturing industries have no international comparative advantage. Therefore, after accession, China's capital-intensive and technology-intensive manufacturing industries will face significant competition from foreign companies. On the one hand, the enhanced competition can pressure China's domestic enterprises to improve their 
management and technology and, therefore, to increase efficiency. On the other hand, more domestic enterprises might face the possibility of being forced out of business. This is especially critical for those loss-making SOEs in the traditional capital-intensive industries.

SOE reform is essential to ensuring smooth accession to the WTO and is also very important for the successful implementation of China's WTO commitments. Currently, China's capital-intensive and technology-intensive manufacturing industries are still overwhelmingly dominated by SOEs. The successful reform of China's state sector will depend greatly on the means undertaken and the tools made available to foreign investors. Although the Chinese Government has allowed private capital participation in the restructuring and modernisation of SOEs, controls over foreign ownership and the forms of foreign investment, such as cross-border M\&As, still exist.

Foreign companies in capital-intensive and technology-intensive industries have superior ownership advantages over China's domestic enterprises, and therefore have more advantages in investing and competing in China's capital-intensive and technology-intensive industries. If the Chinese Government further relaxes the controls over foreign ownership, allows direct transactions of cross-border M\&As of China's enterprises (especially SOEs) by foreign companies, and effectively protects intellectual property rights, greater volumes of FDI-especially large multinational enterprises (MNEs) from industrial countries-will flow into China's capitalintensive and technology-intensive manufacturing industries. The most promising industries will be the new and high-technology industries, such as electronics, telecommunications equipment, synthetic materials, new-type building materials, pharmaceuticals and automobiles.

The automobile industry is the only manufacturing industry in which China has made specific commitments in investment liberalisation in the WTO agreements. The industry was one of the earliest industries opened to foreign investors in China. In 1984, two joint ventures were set up: Beijing Jeep Corporation LTD (Beijing/ United States) and Shanghai Volkswagen Automobile Corporation (Shanghai/Germany). By the end of 1998, more than 400 Sino-foreign joint ventures had been approved in the automobile industry. The largest joint ventures are in Shanghai (Shanghai Volkswagen, Shanghai General Motors), Changchun (FAW-Volkswagen), Wuhan (DongFeng-Citroen) and Guangzhou (Peugeot, Honda).

China is a potentially large market for an automobile industry. Currently, China's 
annual production of motor vehicles is around 1.7 million. With rapid economic development and the increase of per capita income, demand for motor vehicles in China will increase rapidly. With China's accession to the WTO, import tariffs on motor vehicles will be reduced from the current level of 80-100 per cent to 25 per cent by 2006, and tariffs on auto parts will be cut to an average of 10 per cent by 2006. Undoubtedly, after China's accession to the WTO more motor vehicles will be imported to meet China's rapidly increasing domestic demand. However, domestic producers of motor vehicles will still be the main supplier for domestic automobile demand. Therefore, foreign automobile companies with superior technology, advanced production techniques, high managerial skills and rich experiences in international competition have tremendous advantages to invest in China's automobile industry. Furthermore, direct participation in local auto production will also be the most efficient way to secure foreign auto companies' shares in China's domestic automobile markets.

Currently, FDI in China's automobile industry faces some policy restrictions. For example, there are restrictions on the share of foreign ownership. Wholly foreignowned enterprises are not allowed. There are also restrictions on production range and local content requirement. Furthermore, foreign investors are not allowed to invest and operate in motor vehicle distribution and maintenance.

China has made some specific commitments in investment liberalisation in the automobile industry after its accession to the WTO. The key points include: allowing non-bank foreign financial institutions to provide auto financing; commitments regarding importation, distribution, sale, and maintenance and repair of automobiles; freedom to determine product range within two years of accession; reduction of red tape, as provincial authorities will be empowered to authorise investments in the sector worth up to US $\$ 150$ million (currently US $\$ 30$ million) four years after accession; and allowing wholly foreign-owned enterprises to compete in engine manufacturing.

China's commitments in investment liberalisation in the automobile industry provide great opportunities for foreign investors to invest in the industry in China. It is expected that foreign investment in China's automobile industry will increase significantly after China's accession to the WTO.

\section{Services sector}

Service is the most restricted economic sector and the latest to be opened to foreign investors. To date, the Chinese Government has opened some services 
industries to FDI, mainly in the east region, in an experimental fashion, such as finance, insurance and commerce. By the end of 2000, the services sector has received FDI of US $\$ 127$ billion, of which US $\$ 83$ billion was in the real estate industry and only US $\$ 44$ billion in other services industries. Therefore, the other services industries (excluding the real estate industry) accounted for only 13 per cent of the total FDI in China due to very limited openness and the tight restrictions on FDI in these services industries.

China's services sector is underdeveloped in the national economy. For the last half-century, the share of the services sector in China's GDP has been around 30 per cent. By international comparison, the development of China's services sector is also relatively low. According to the purchasing power parity (PPP) calculation, China's current per capita GDP is around US $\$ 3000$. At the global level, the average share of the services sector in national GDP is around 50 per cent when per capita GDP is around US $\$ 3000$ (based on PPP). However, the share of China's services sector in national GDP is 20 percentage points lower than the world average. Therefore, China's services sector not only lags behind the overall development of its national economy, but is also underdeveloped by international standards. Although the Chinese Government issued the 'Decisions on Accelerating the Development of the Services Sector' in the early 1990s, the targets set for the development of the services sector have not been achieved. The slow development of the services sector may well become a bottleneck, affecting the future overall development of China's economy.

There are many reasons for the slow development of China's services sector, but two stand out. One is closedness and the other is monopoly. During the last two decades of economic reform and opening up to the outside world, China's services sector has actually been relatively closed to foreign direct participation. Although the Chinese Government has gradually opened some services industries to foreign investors in a very restricted and experimental fashion, many services industries are still closed to foreign investors. The closed nature of the services sector to foreign competition has effectively protected the state monopoly in the services sector. At present, China's many services industries are monopolised by SOEs, especially in the industries of finance, telecommunications and in international trade.

Opening the services sector has been one of the most important issues in the bilateral negotiations of China's accession to the WTO. China has made some important and concrete commitments to the WTO in opening its services sector to 
foreign investors. Undoubtedly, after China's accession and with the implementation of the commitments, there will be a surge of FDI inflows to China's services sector. In the services sector, the following industries are likely to attract foreign investment.

Finance. China started to allow FDI in the finance industry in an experimental fashion in a number of selected cities in 1982. At present, China has eliminated the geographical restrictions on setting up operational branches by foreign financial institutions. By the end of 2000 , there were 177 operational foreign-invested financial institutions and 238 representative offices set up by foreign banks in China. Foreign-invested financial institutions are mainly engaged in foreign currency business. However, 32 foreign-invested financial institutions in Shanghai and Shenzhen are permitted to engage in renminbi business. At the beginning of 2000 , the People's Bank of China announced that foreign-invested banks in Shanghai can extend their RMB business to Jiangsu and Zhejiang provinces, and foreign-invested banks in Shenzhen can extend their renminbi business to Guangdong, Guangxi and Hunan provinces.

By mid 1999, total assets of foreign-invested financial institutions were US $\$ 32$ billion, accounting for less than 2 per cent of the total assets of Chinese financial institutions. Total outstanding loans of foreign-invested financial institutions were US $\$ 24$ billion, also accounting for less than 2 per cent of the total outstanding loans of Chinese financial institutions. Undoubtedly, there are great business opportunities for foreign investors in China's financial industry. China has committed upon accession to the WTO to further open its financial markets, eliminate regional and geographical restrictions, and permit more foreign-invested financial institutions to engage in renminbi business. Therefore, China's financial industry will attract a large volume of FDI inflows after China's accession to the WTO.

Insurance. In 1992, China conditionally opened its insurance markets, allowing foreign insurance institutions to set up two types of foreign-invested insurance institutions in an experimental fashion in Shanghai; branches of foreign insurance companies, and joint venture insurance companies. In 1995, the experiment was extended to Guangzhou. By the end of 2000 , there were 26 foreign-invested operational insurance companies and institutions in China. In addition, the People's Bank of China has also approved two foreign insurance intermediary institutions and 196 representative offices. Currently, China is stipulating 'Management Provisions on Foreign-Invested Insurance Institutions'. 
The main policy constraints to FDI in China's insurance industry are market access, regional and geographical restrictions, restrictions on business scope, and controls over foreign ownership. However, China has made some concrete commitments to opening its insurance industry to foreign investors after accession to the WTO.

China's insurance industry has registered double-digit revenue growth for several consecutive years. Total income from premiums is likely to top US $\$ 18$ billion in 2001. As predicted by the China Insurance Regulatory Commission (CIRC), total insurance revenues will reach US $\$ 30$ billion in 2004. Therefore, China's insurance industry has great potential to attract FDI provided China implements the WTO agreement and further open its insurance industry.

Telecommunications. China's regulations currently prohibit FDI in the operation and management of the telecommunications industry. In the 'Industrial Guidance on Foreign Direct Investment', the telecommunications industry is listed as a prohibited sector for foreign investment. However, China has made some commitments to the WTO to open its telecommunications industry to foreign investors after the accession.

China's telecommunications industry has been monopolised by state-owned companies. Foreign companies with advanced equipment and technology have shown great interests in investing in China's telecommunications industry, especially in value-added services investment. Therefore, China's WTO accession will not only provide an opportunity for foreign investors to enter China's huge telecommunications market, but also will increase domestic competition in the telecommunications market, thus increasing the industry's efficiency and benefiting consumers.

Domestic commerce. In 1992 China decided to set up several Sino-foreign joint ventures engaging in domestic commercial retail business at an experimental base in each of the following cities and areas: Beijing, Tianjin, Shanghai, Guangzhou, Qingdao and the five special economic zones. Later, China decided to set up two Sino-foreign joint venture chain retail stores in Beijing and Shanghai and to set up a number of mainland and Taiwan joint ventures engaging in domestic commercial retail business in inland areas, also in an experimental fashion. In June 1999, the State Economic and Trade Commission and the Ministry of Foreign Trade and Economic Cooperation (MOFTEC) under the approval of the State Council jointly issued 'The Experimental Methods for Foreign-Invested Commercial Enterprises'. The experiment on joint ventures engaging in domestic commercial retail business was extended to all provincial capital cities, and at the same time, an experiment on 
setting up foreign-invested enterprises engaging in domestic commercial wholesale business was implemented.

At the end of 2000, there were 27 foreign-invested commercial retail enterprises and one foreign-invested commercial wholesale enterprise approved by the central government. ${ }^{4}$ There were about 277 foreign-invested commercial retail enterprises approved by local governments at the provincial level.

The current policy restrictions on FDI in the domestic commerce industry mainly include controls over foreign ownership, the degree of market access, business scope and geographical restrictions.

China has committed to increase the number of foreign-invested commercial enterprises, to expand the geographical areas for FDI in domestic commerce, to release restrictions on FDI in wholesale business, and to eliminate the limit of 50 per cent equity participation for large retailers.

China's huge domestic commercial markets, with annual retail sales of 3 trillion yuan, are very attractive to foreign investors. However, due largely to the policy constraints, foreign-invested commercial enterprises account for only 1 per cent of the total value of retail sales in China. With China's accession to the WTO and the further opening up of China's domestic commercial markets, foreign investors will have a great opportunity to invest in China's domestic commercial industry.

International trade. Foreign investors are allowed to set up trading enterprises in the 13 tax-bounded zones to conduct entrepot trade and serve as import and export agents for the enterprises in the tax-bounded zones. In September 1996, MOFTEC issued 'The Provisional Methods on the Experiment of Setting up China and Foreign Joint Venture International Trading Company'. China allowed foreign investors to set up Sino-foreign joint international trading companies in Shanghai Pudong area and Shenzhen special economic zone in an experimental fashion. The joint international trading companies can engage in commodity and technology import and export business except for 16 export commodities and 14 import commodities that are subject to state trading and control. At present, the experiment has approved five foreign-invested international trading companies outside the tax-bounded zones, of which three are in Shanghai and two in Shenzhen.

Currently, there are many restrictions on foreign investors setting up international trading business in China. However, with China's accession to the WTO and further trade liberalisation, restrictions on foreign investors conducting international trading business will slowly be lifted. Foreign trading companies with their rich experiences 
and well-developed international market network will certainly play a very important role in promoting China's international trade. Currently, MOFTEC is reviewing the regulations and policies governing FDI in the international trade sector, preparing to further open the sector to foreign investors, and extend the experiment of FDI in the international trade sector to the central and western areas of China.

\section{CONCLUSION}

In terms of investment liberalisation, China's commitments are mainly in the automobile industry and some key industries of the services sector. WTO negotiations will have an impact on China's FDI policy regime, but the WTO accession agreements have not significantly affected China's FDI policy regime. The limitations are mainly due to the limited effect the WTO has on investment policies. Therefore, unilateral reduction and elimination of investment barriers would still be the main task of further investment liberalisation in China.

WTO entry will have a positive impact on FDI inflows to China. However, whether China benefits from WTO entry and realises its potential to attract FDI inflows after entering the WTO, largely depends on how China implements the WTO agreements, fulfils its WTO commitments, further reduces and eliminates trade and investment barriers and further opens domestic markets, manages internal economic reforms (particularly the reform of SOEs), and enforces the protection of intellectual property rights.

China's accession to the WTO provides a great opportunity for China to improve and diversify its FDI sources and, therefore will have a significant impact on the composition of FDI sources in China. In general, with the implementation of trade and investment liberalisation after China's accession, both developing and industrial economies are likely to increase their investments in China as a result of the improved investment environment and the reduction of trade and investment barriers in China. However, while China will remain a very important host for investment from developing economies - particularly the NIEs-China will become an increasingly important destination for industrial economy investments as China progressively strengthens intellectual property rights protection, opens more economic sectors (especially the services sector) to FDI, and encourages cross-border mergers and acquisitions (M\&As). This will not only increase total FDI inflows, but also the quality of FDI inflows into China.

In terms of regional distribution of FDI inflows after China's accession, the study 
reveals that in the short run, uneven regional economic development, and hence, the uneven regional distribution of FDI between the east region and the central and west regions in China will probably be exacerbated. However, in the medium and long term, with the implementation of the West Development Strategy, and economic development in the central and west regions, it is reasonable to expect that more FDI will gradually flow into the central and west regions.

The study also reveals that the sectoral distribution of FDI in China will experience some major changes after China's accession. The general trend will be for the share of FDI inflows into the manufacturing sector is gradually to decline while the share of FDI inflows into the services sector increases significantly. Opening the services sector has been one of the most important issues in the bilateral negotiations of China's accession to the WTO. China has made some important and concrete commitments to the WTO in opening its services sector to foreign investors. Therefore, it is expected that after accession, there will be a surge of FDI inflows to China's services sector, especially into finance, insurance, telecommunications, domestic commerce and auxiliary services industries.

\section{Notes}

The empirical model is a multi-regression model with pooled data. The data set contains 32 developing countries (including China) for a period of 12 years from 1987-98. The dependent variable is FDI inflows into developing countries, and the independent variables include market size (GDP), GDP growth rate, efficiency wage (defined as the real wage rate adjusted by labour productivity), labour quality (approximated by illiteracy rate of the population), and economic distance (defined as the weighted average distance of a developing economy to the rest of the world, where the weights are the shares of the economies' GDP in total world GDP). In the regression the independent variables are lagged by one year. All the independent variables are statistically significant at the 1 per cent significance level, and the Buse- $R^{2}$ is 0.55 , which indicates the relatively high explanatory power of the estimated equation. For more details of the model, see Chen Chunlai (2000).

2 The east region includes Beijing, Tianjin, Hebei, Liaoning, Shanghai, Jiangsu, Zhejiang, Fujian, Shandong, Guangdong, Guangxi and Hainan. The central region includes Shanxi, Inner Mongolia, Jilin, Heilongjiang, Anhui, Jiangxi, Henan, Hubei and Hunan. The west region includes Sichuan, Guizhou, Yunnan, Tibet, Shaanxi, Gansu, Qinghai, Ningxia and Xinjiang. 
${ }_{3}$ According to the Strategy, the areas include 12 provinces, municipalities and autonomous regions: Sichuan, Chongqing, Guizhou, Yunnan, Gansu, Shaanxi, Qinghai, Ningxia, Xinjiang, Tibet, Guangxi and Inner Mongolia; and two prefectures: Enshi of Hubei Province and Xiangxi of Hunan Province.

${ }^{4}$ Each enterprise may have several operating stores. 